Ahmed I. Ramadan, et al., Shear Response Investigation of Hsrc Deep Beams without Web Reinforcement Part I: Comparison of Design Equations, pp. 1432 - 1446

\title{
SHEAR RESPONSE INVESTIGATION OF HSRC DEEP BEAMS WITHOUT WEB REINFORCEMENT PART I: COMPARISON OF DESIGN EQUATIONS
}

\author{
Aly G. Aly Abd-Elshafy, Ahmed I. Ramadan *, Mahmoud H. Ahmed and Atif M. Abdel-Hafez \\ Civil Engineering Department, Faculty of Engineering, Assiut University, Assiut, Egypt
}

Received 17 April 2013, accepted 12 June 2013

\begin{abstract}
Currently, there is no general agreement on a theory describing the response of reinforced concrete members without web reinforcement. Many structural systems are usually performed using empirical or semi-empirical expressions provided by codes of practice that do not consider the influence of many governing parameters. In this paper, a comparison between values of current experimental shear strength and those of various international design approaches like ACI, Canadian, FIB and the method proposed by Sudheer, Zararis ,Zsutty ,Shah ,Bazant and Russo. Eighteen simple span high strength reinforced concrete "HSRC" deep beams without web reinforcement were tested and analyzed under two static point loads at mid-span of the beam to examine the contribution of various parameters on the shear capacity of HSRC beams. The main studied parameters are f'cu=50 MPa, three values of tension reinforcement- $\rho \%-(0.73 \%, 1.21 \%$ $\& 1.83 \%)$ and shear span to effective depth ratio-a/d-( 2,1.5 \&1). As a conclusion of this paper, ACI and FIB code provisions for shear in HSC are safe for use with the exception that CSA should be used with care. Despite numerous studies, there is still a need to develop a clear understanding of the shear behavior of HSC beams without web reinforcement. Therefore, this experimental program was arranged to evaluate the shear behavior and to increase the shear database on HSRC deep beams.
\end{abstract}

Keyword: deep beams, high strength concrete, tension reinforcement ratio, shear span to effective depth ratio, shear strength.

\section{Introduction}

There is a general agreement among the researchers in the field of structural engineering and concrete technology that the shear strength of high strength reinforced concrete (HSRC) beams, unlike the normal strength reinforced concrete (NSRC) does not increase, in the same proportion as the increase in the compressive strength of concrete, due to brittle behavior of the High Strength Concrete. Hence the current empirical equations proposed by most of the building codes for shear strength of HSRC beams are less conservative as compared NSRC beams. This major observation by the researcher is the main focus of this research.

Reinforced concrete is being used extensively in the construction industry all over the world. The calculation of stresses in concrete is difficult due to its heterogeneous nature and inclusion of reinforcement further complicates the situation. Extensive research work on shear behavior of normal as well as high-strength concrete beams has been carried out all over the world. The major researchers include Ferguson [11], Taylor [12], Cossio [13], Berg [14], Mathey and Watstein [15], Zsutty [16], Kani [17], Elzanaty [18], Roller and Russel [19], Ahmad and Lue [20], Barrington[21], Shin et al. [22], Kim and White [23], Tompos and Frosh [24], Ahmad

Corresponding author.

E-mail address: a.i.h.r1978@gmail.com 
Ahmed I. Ramadan, et al., Shear Response Investigation of Hsrc Deep Beams without Web Reinforcement Part I: Comparison of Design Equations, pp. 1432 - 1446

[25], Reineck [26]. Despite the extensive research work, shear behavior of high-strength reinforced concrete beams is still controversial and needs further research.

Factors Affecting Shear Strength of Reinforced Concrete Beams without web reinforcement are shear span to effective depth ratio $(\mathrm{a} / \mathrm{d})$, tensile steel ratio ( $\rho \%)$, aggregate type, strength of concrete, type of loading, and support conditions, etc. In this research, shear span-to-effective depth ratio and tensile steel ratio were the main variables considered.

- Shear Span to Effective Depth Ratio (a/d): Many researchers have shown that failure mode is strongly dependent on the shear span to depth ratios (a/d). Berg [13] finds increase in shear capacity with decrease of a/d ratio. However Ferguson [10] describes this increased resistance to diagonal tension with small a/d, a local loading effect due to direct transfer of load to supports through concrete compression. Taylor [11] found increase in diagonal cracking load with increase in shear span for concrete compressive strength up to $27.59 \mathrm{MPa}$. For concrete compressive strength ranging from 17.24 $\mathrm{MPa}$ to $34.48 \mathrm{MPa}$, Kani [16] found a decrease in relative flexural strength with increase in $\mathrm{a} / \mathrm{d}$ ratio up to about 2.5 .

- Tensile Steel Ratio: The shear strength of a beam increases with increase in longitudinal steel ratio. Barrington [21] confirmed a strong relationship between cracking shear and steel ratio in lightly reinforced beams having steel ratio $<0.015$. Berg [14] found a highly significant correlation between the nominal shear strength and the percentage tension reinforcement. Ahmad and Lue [20] carried out a research and found that for very low steel ratios, the relative flexural strength increases as the tensile steel ratio ' $\rho$ ' decreases.

- Size Effect: the basic theory of size effect in the shear failure of reinforced concrete beams was formulated more than two decades ago and experimental evidence has become great, ACI 318-11 Code has not adopted size effect provisions for beams of depths d up to $0.6 \mathrm{~m}$ and even $1 \mathrm{~m}$. The ACI-445F database [26] for shear strength of longitudinally reinforced concrete beams with no stirrups (ACI Committee 445), obtained mostly under three or four-point bending (beams under distributed load are excluded), has a bias of two types: 1) crowding of the data in the small size range: $86 \%$ of the 398 data points pertain to beam depths less than $0.5 \mathrm{~m}$ and $99 \%$ to depths less than $1.1 \mathrm{~m}$, whereas only $1 \%$ of data pertains to depths from 1.2 to $2 \mathrm{~m}$; and 2) strongly dissimilar distributions, among different size intervals, of the subsidiary influencing parameters, particularly the longitudinal steel ratio, shear span ratio (a/d).

Almost, all of research studies mentioned above had done on non-practical beam size, which will led to less accurately in results.

\section{Experimental program}

\section{1. Test Specimens}

Extensive research work has also been carried out on the shear behavior of eighteen HSRC deep beams, two groups; nine deep beams each, without web reinforcement, summarized in Table 1 and dimension details shown in Fig. 1, were tested. the first group $\mathrm{h}=700 \mathrm{~mm}, 3600 \mathrm{~mm}$ length, the second group $\mathrm{h}=400 \mathrm{~mm}, 3000 \mathrm{~mm}$ length, and all groups with three values of tensile reinforcement $(0.73 \%, 1.21 \% \& 1.83 \%)$ and three values of shear span to effective depth ratio $(2,1.5 \& 1)$ were mainly selected to study the behavior of short beams, where typical shear failure can be anticipated. These beams were tested under

Journal of Engineering Sciences, Assiut University, Faculty of Engineering, Vol. 41, No. 4, July, 2013,E-mail address: jes@aun.edu.eg 
1434

Ahmed I. Ramadan, et al., Shear Response Investigation of Hsrc Deep Beams without Web Reinforcement Part I: Comparison of Design Equations, pp. 1432 - 1446

two static point loads at mid-span of the beam to examine the contribution of various parameters like longitudinal steel, shear span to depth ratio, and beam span, on the shear capacity of HSRC beams. All these tested beams are carried out at Structure laboratory of Engineering College, King Saud University, Riyadh, Kingdom of Saudi Arabia.

Table 1.

Specimen Details

\begin{tabular}{|c|c|c|c|c|c|c|c|c|c|c|c|c|}
\hline No & $\begin{array}{c}\text { Beam } \\
\text { Designation }\end{array}$ & $\begin{array}{c}h \\
m m\end{array}$ & $\begin{array}{c}a \\
m m\end{array}$ & $d$ & $a / d$ & $a_{h}$ & $a_{r}$ & $S_{s}$ & $r$ & $\begin{array}{c}L \\
m m\end{array}$ & $\begin{array}{c}\rho_{s} \\
(\%)\end{array}$ & $f_{c u}^{\prime}$ \\
\hline 10 & B700-2-50-r1 & 700 & 1224 & 660 & 2 & 500 & 326 & 200 & 1 & 3600 & 0.73 & 51.8 \\
\hline 11 & B700-2-50-r2 & 700 & 1224 & 660 & 2 & 500 & 326 & 200 & 2 & 3600 & 1.21 & 51.8 \\
\hline 12 & B700-2-50-r3 & 700 & 1224 & 660 & 2 & 500 & 326 & 200 & 3 & 3600 & 1.83 & 51.8 \\
\hline 13 & "B700-1.5-50-r1 & 700 & 9918 & 6600 & 1.5 & 1100 & 332 & 800 & 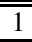 & 3600 & 0.73 & 51.8 \\
\hline 14 & B700-1.5-50-r2 & 700 & 918 & 660 & 1.5 & 1100 & 332 & 800 & 2 & 3600 & 1.21 & 51.8 \\
\hline 15 & B700-1.5-50-r3 & 700 & 918 & 660 & 1.5 & 1100 & 332 & 800 & 3 & 3600 & 1.83 & 51.8 \\
\hline 16 & B700-1-50-r1 & 700 & 1600 & 660 & 1 & "674 & 326 & 1000 & 1 & 3600 & 0.73 & 51.8 \\
\hline 17 & B700-1-50-r2 & 700 & 1600 & 660 & 1 & 674 & 326 & 1000 & 2 & 3600 & 1.21 & 51.8 \\
\hline 18 & B700-1-50-r3 & 700 & 1600 & 660 & 1 & 674 & 326 & 1000 & 3 & 3600 & 1.83 & 51.8 \\
\hline 28 & B400-2-50-r1 & 400 & 670 & 360 & 2 & 1000 & 330 & 800 & 1 & 3000 & 0.73 & 48.35 \\
\hline 29 & B400-2-50-r2 & 400 & 670 & 360 & 2 & 1000 & 330 & 800 & 2 & 3000 & 1.21 & 48.35 \\
\hline 30 & B400-2-50-r3 & 400 & 670 & 360 & 2 & 1000 & 330 & 800 & 3 & 3000 & 1.83 & 48.35 \\
\hline 31 & "B400-1.5-50-r1 & 400 & "502.5 & 360 & 1.5 & 1300 & 348 & 1000 & 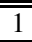 & 3000 & (0.73 & 48.35 \\
\hline 32 & B400-1.5-50-r2 & 400 & 502.5 & 360 & 1.5 & 1300 & 348 & 1000 & 2 & 3000 & 1.21 & 48.35 \\
\hline 33 & B400-1.5-50-r3 & 400 & 502.5 & 360 & 1.5 & 1300 & 348 & 1000 & 3 & 3000 & 1.83 & 48.35 \\
\hline 34 & B400-1-50-r1 & 4400 & 335 & 360 & 1 & 1600 & 365 & 1000 & 1 & 3000 & 0.73 & 48.35 \\
\hline 35 & B400-1-50-r2 & 400 & 335 & 360 & 1 & 1600 & 365 & 1000 & 2 & 3000 & 1.21 & 48.35 \\
\hline 36 & B400-1-50-r3 & 400 & 335 & 360 & 1 & 1600 & 365 & 1000 & 3 & 3000 & 1.83 & 48.35 \\
\hline
\end{tabular}

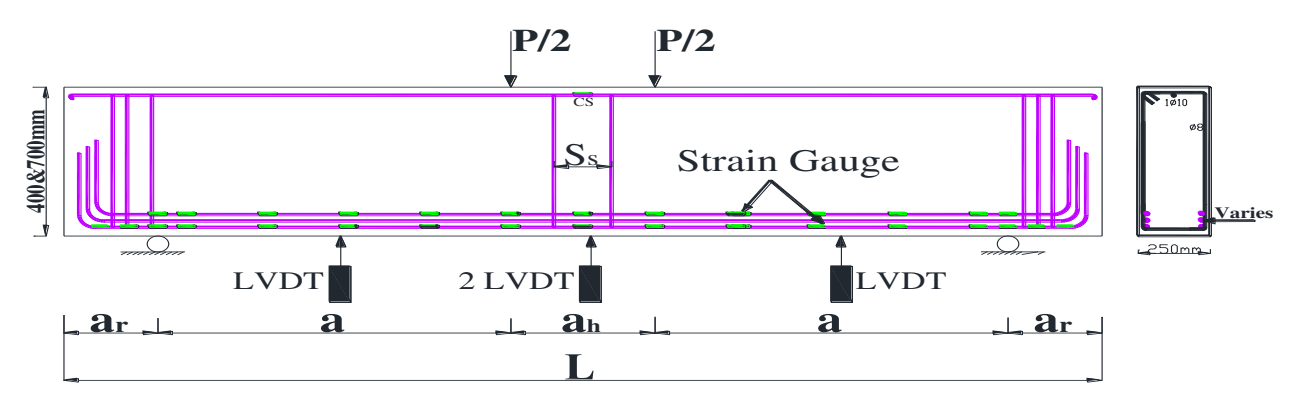

Fig. 1. Details of Specimen

\section{2. Materials}

The beams are constructed using concrete provided by a local ready-mix supplier. The concrete mix was placed in the forms and vibrated to ensure workability of the concrete. Concrete cylinders $150 \times 300 \mathrm{~mm}$ are cast during casting the beams and cured under the same conditions, at room temperature for 28 days, as the tested beams. The concrete strength was monitored by compression testing of the cylinders. The strength of the

Journal of Engineering Sciences, Assiut University, Faculty of Engineering, Vol. 41, No. 4, July, 2013,E-mail address: jes@aun.edu.eg 
Ahmed I. Ramadan, et al., Shear Response Investigation of Hsrc Deep Beams without Web Reinforcement Part I: Comparison of Design Equations, pp. 1432 - 1446

concrete ranged from $48 \mathrm{MPa}$ to $52 \mathrm{MPa}$ with an average value of $50 \mathrm{MPa}$ at the age of 28 days.

Four diameters of high strength deformed bars 10, 12, 14, 18, and $20 \mathrm{~mm}$ and of 765 , 650, 670, 670, and $670 \mathrm{MPa}$ proof strengths respectively were used for longitudinal reinforcement. $8 \mathrm{~mm}$ plain bars were used for transverse reinforcement.

\section{3. Test procedure}

Each specimen was tested as a simply supported beam under four point loading, Fig. 2. Two point loads were applied by hydraulic jacks in a load frame. In testing, four LVDT was calibrated, two at middle of span and one at each of middle of shear span. Specimens were loaded at a constant rate and deflection was recorded. The cracks and crack pattern was noted at each increment of load. The test was continued in the same manner until the specimen failed. On the day of testing, all cylinders were also tested in accordance with ASTM C39-86. Fig. 3 to Fig. 8 show details of tested beam's dimensions, steel details and strain gauges positions on steel bars and upper concrete surface fiber.

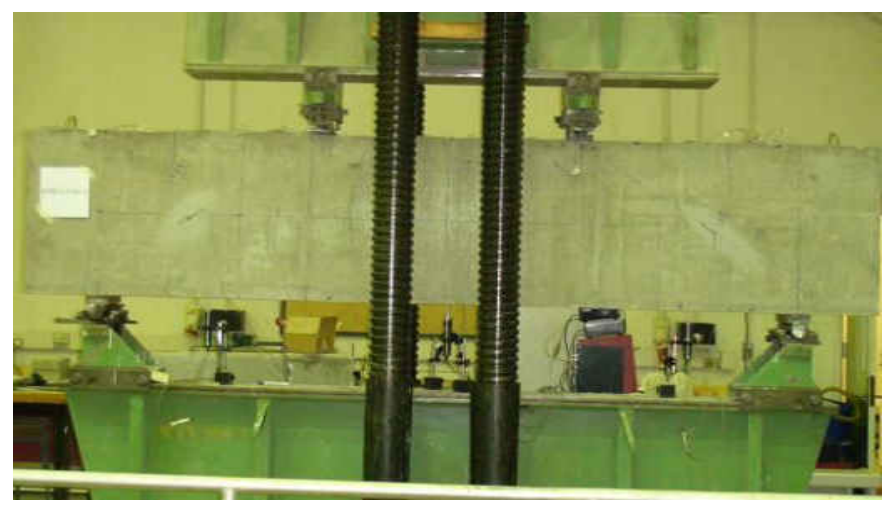

Fig. 2. Test Setup of test Specimens

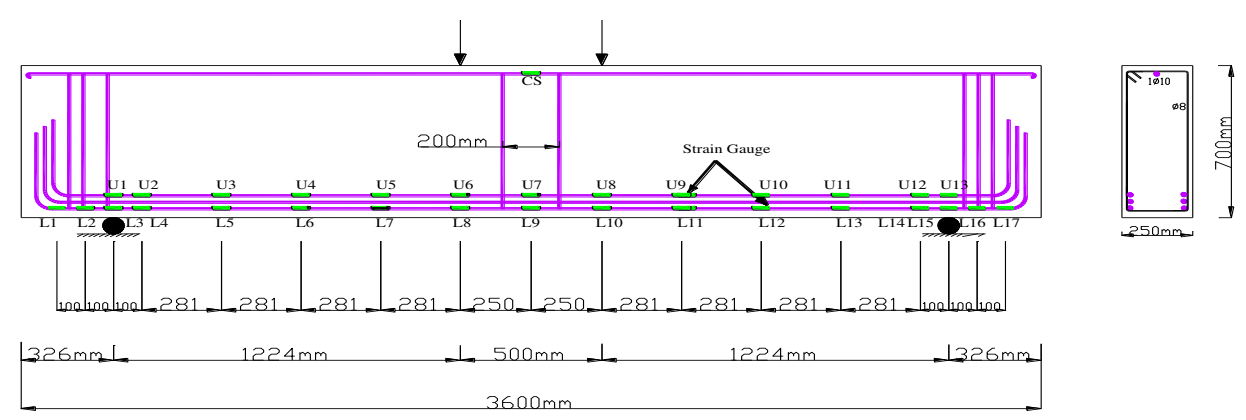

Fig. 3. Beams $(10,11,12)$; Dimensions, steel details and strain gauges positions

Journal of Engineering Sciences, Assiut University, Faculty of Engineering, Vol. 41, No. 4, July, 2013,E-mail address: jes@aun.edu.eg 
Ahmed I. Ramadan, et al., Shear Response Investigation of Hsrc Deep Beams without Web Reinforcement Part I: Comparison of Design Equations, pp. 1432 - 1446

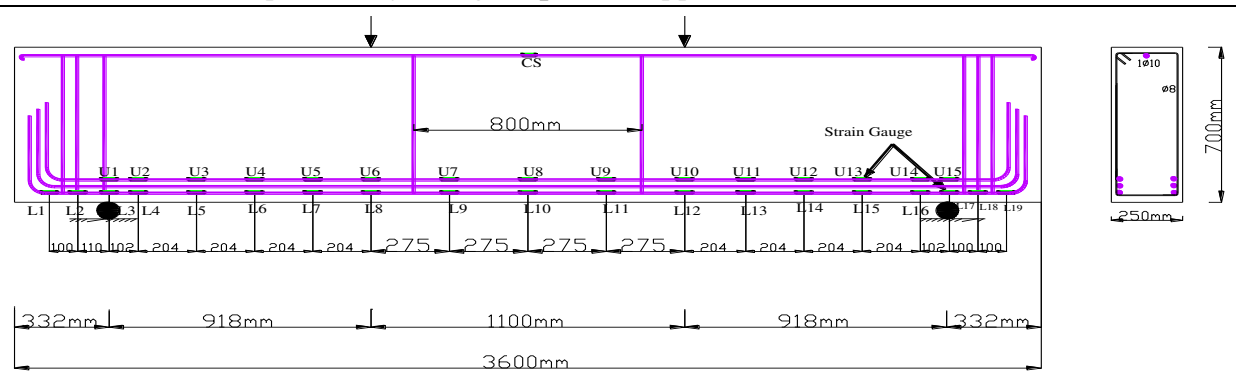

Fig. 4. Beams (13, 14, 15); Dimensions, steel details and strain gauges positions
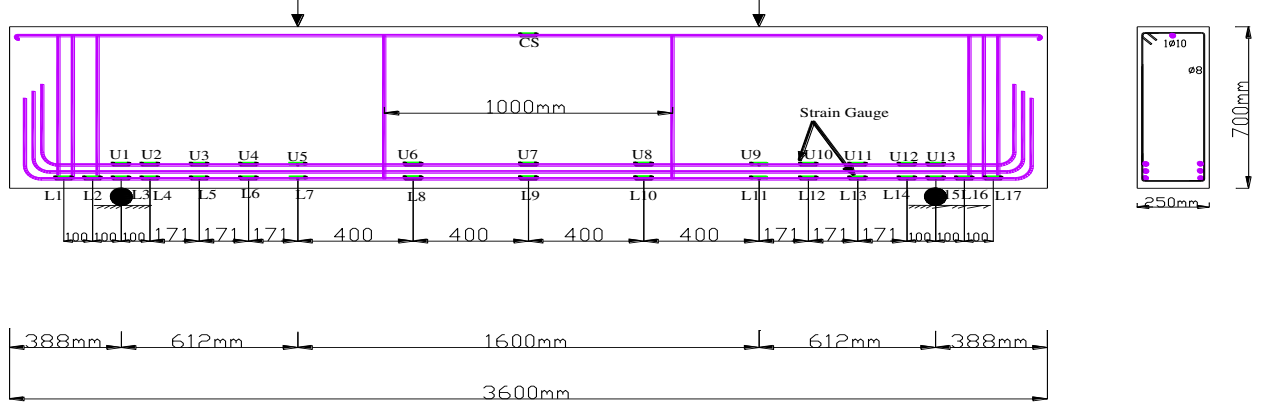

Fig. 5. Beams $(16,17,18)$; Dimensions, steel details and strain gauges positions
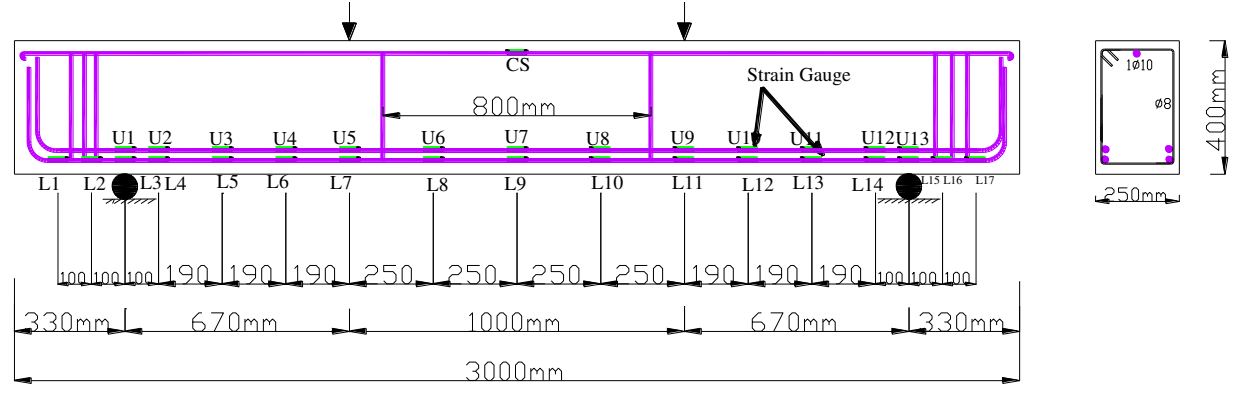

Fig. 6. Beams $(28,29,30)$; Dimensions, steel details and strain gauges positions
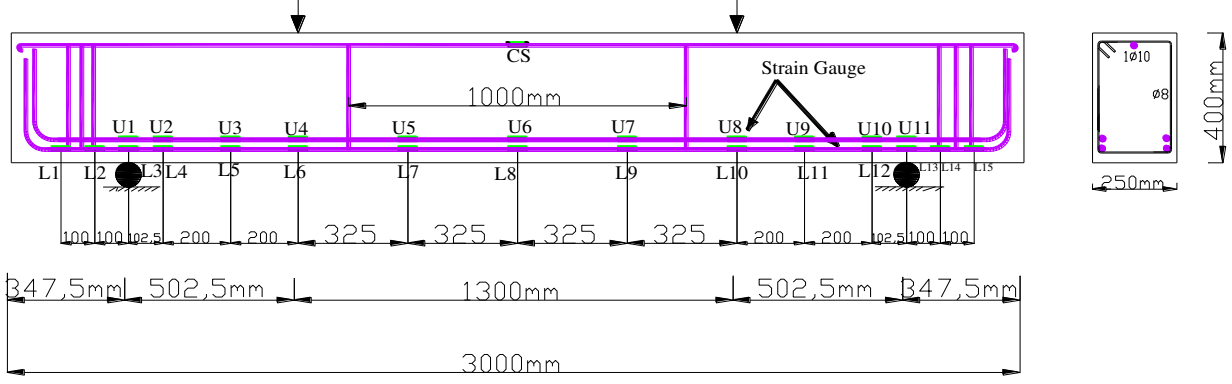

Fig. 7. Beams $(31,32,33)$; Dimensions, steel details and strain gauges positions

Journal of Engineering Sciences, Assiut University, Faculty of Engineering, Vol. 41, No. 4, July, 2013, E-mail address: jes@aun.edu.eg 
Ahmed I. Ramadan, et al., Shear Response Investigation of Hsrc Deep Beams without Web Reinforcement Part I: Comparison of Design Equations, pp. 1432 - 1446

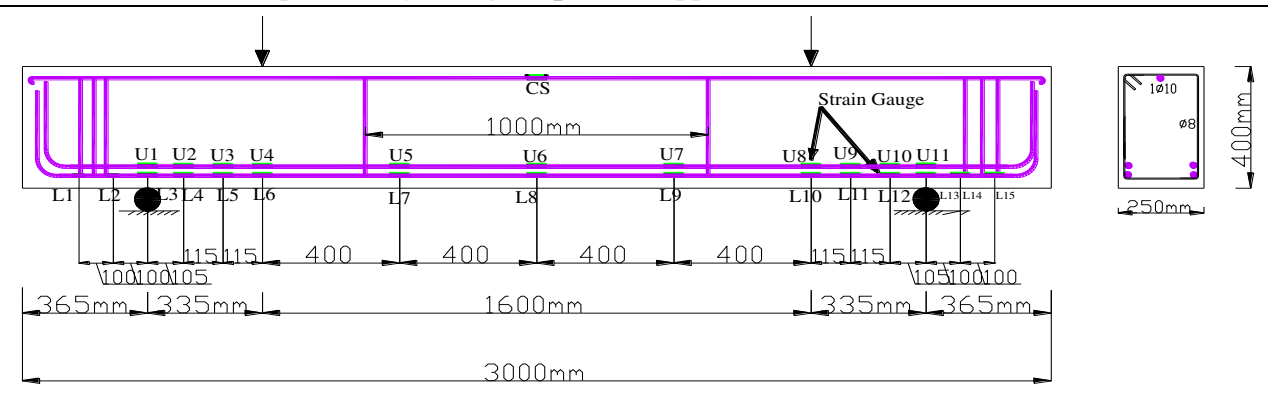

Fig. 8. Beams $(34,35,36)$; Dimensions, steel details and strain gauges positions

\section{Results and discussion}

\section{1. Results}

The measured load, deflection, crack development and failure of each of the eighteen tested specimens were recorded. Cracks were marked on each of the beams throughout testing to failure. All the calculations have been done based on the compressive strength of concrete cylinders. Moreover, the shear strength of the concrete beams has been calculated using different design approaches and compared with the experimental results. The tests results for the experimental program are summarized in Table 2.

\section{Table 2.}

Comparison of VTest results with proposed equation and shear design equations

\begin{tabular}{|c|c|c|c|c|c|c|c|c|c|c|c|}
\hline \multirow{2}{*}{$\begin{array}{c}\text { Beam } \\
\text { No. }\end{array}$} & \multirow{2}{*}{$\begin{array}{c}\text { Test Beam } \\
\text { Designation }\end{array}$} & \multicolumn{10}{|c|}{ Shear Strength $(\mathrm{KN})$} \\
\hline & & $V_{A C I}$ & $V_{C S A}$ & $V_{F I B}$ & $V_{S I P}$ & $V_{\text {Zararis }}$ & $V_{\text {Bazant }}$ & $V_{\text {Zsutty }}$ & $V_{\text {Russo }}$ & $V_{\text {Shah }}$ & $V_{\text {Test }}$ \\
\hline 10 & B700-2-50-r1 & 197.7 & 233.3 & 143.4 & 347.2 & 284.9 & 123.1 & 277.6 & 133.8 & 206.9 & 281.0 \\
\hline 11 & B700-2-50-r2 & 205.0 & 233.3 & 169.7 & 447.0 & 295.3 & 146.4 & 328.5 & 181.9 & 247.1 & 498.5 \\
\hline$\overline{12}$ & B700-2-50-r3 & 214.4 & 233.3 & 194.7 & 549.8 & 301.3 & 169.0 & 377.1 & 235.9 & 298.9 & 469.9 \\
\hline 13 & B700-1.5-50-r1 & 201.4 & 233.3 & 154.1 & 400.9 & 305.0 & 125.9 & 407.3 & 195.1 & 224.1 & 503.5 \\
\hline 14 & B700-1.5-50-r2 & 211.1 & 233.3 & 182.3 & 516.2 & 316.1 & 151.9 & 482.1 & 275.2 & 264.2 & 699.9 \\
\hline 15 & B700-1.5-50-r3 & 223.6 & 233.3 & 209.2 & 634.8 & 322.5 & 178.7 & 553.3 & 367.5 & 316.1 & 644.1 \\
\hline 16 & B700-1-50-r1 & 195.1 & 233.3 & 134.1 & 303.7 & 325.1 & 150.4 & 267.5 & 334.5 & 241.2 & 721.8 \\
\hline 17 & B700-1-50-r2 & 200.7 & 233.3 & 158.7 & 391.0 & 337.0 & 200.0 & 316.6 & 367.7 & 281.4 & 974.5 \\
\hline 18 & B700-1-50-r3 & 207.9 & 233.3 & 182.1 & 480.8 & 343.8 & 262.1 & 363.4 & 666.4 & 333.3 & 1246.2 \\
\hline 28 & B400-2-50-r1 & 107.8 & 127.3 & 88.0 & 189.1 & 175.3 & 67.3 & 196.7 & 86.6 & 112.9 & 208.1 \\
\hline 29 & B400-2-50-r2 & 111.8 & 127.3 & 104.1 & 243.4 & 181.7 & 80.0 & 178.5 & 117.7 & 134.8 & 225.7 \\
\hline 30 & B400-2-50-r3 & 116.9 & 127.3 & 119.5 & 299.3 & 185.4 & 92.6 & 204.9 & 152.7 & 163.1 & 372.3 \\
\hline 31 & B400-1.5-50-r1 & 109.8 & 127.3 & 94.5 & 218.3 & 181.3 & 69.1 & 221.4 & 126.3 & 122.2 & 280.4 \\
\hline 32 & B400-1.5-50-r2 & 115.1 & 127.3 & 111.8 & 281.1 & 187.9 & 83.7 & 262.0 & 178.1 & 144.1 & 443.0 \\
\hline 33 & B400-1.5-50-r3 & 121.9 & 127.3 & 128.4 & 345.6 & 1427.7 & 99.0 & 300.8 & 237.9 & 172.4 & 537.7 \\
\hline 34 & B400-1-50-r1 & 113.8 & 127.3 & 104.6 & 267.4 & 187.3 & 85.5 & 380.2 & 216.5 & 131.6 & 431.4 \\
\hline 35 & B400-1-50-r2 & 121.7 & 127.3 & 123.8 & 344.2 & 194.1 & 115.8 & 449.9 & 315.4 & 153.5 & 588.0 \\
\hline 36 & B400-1-50-r3 & 131.9 & 127.3 & 142.1 & 423.3 & 198.0 & 154.5 & 516.4 & 431.3 & 181.8 & 765.2 \\
\hline
\end{tabular}

Journal of Engineering Sciences, Assiut University, Faculty of Engineering, Vol. 41, No. 4, July, 2013,E-mail address: jes@aun.edu.eg 
Ahmed I. Ramadan, et al., Shear Response Investigation of Hsrc Deep Beams without Web Reinforcement Part I: Comparison of Design Equations, pp. 1432 - 1446

\section{2. Mode of failures}

Four failure modes are identified, i.e., diagonal splitting (shear) failure, shear-flexure failure, flexure and shear-compression failure. The diagonal-splitting failure, characterized as shear failure, is brittle, sudden and hence treacherous.

A critical diagonal crack joining the loading point at the top and support point at bottom is developed. In the shear-compression mode of failure, $\mathrm{a} / \mathrm{d}=1.5$, after the appearance of the inclined crack, the concrete portion between the top load point experiences high compression and it then finally fails. This mode of failure is equally a brittle mode of failure. The shear-flexure mode of failure is the combined failure in shear and flexure. Flexural cracks are formed followed by the partly diagonal crack. This is ductile mode of failure in which the beam deflects at the center and no explosive sound was heard at the time of failure.

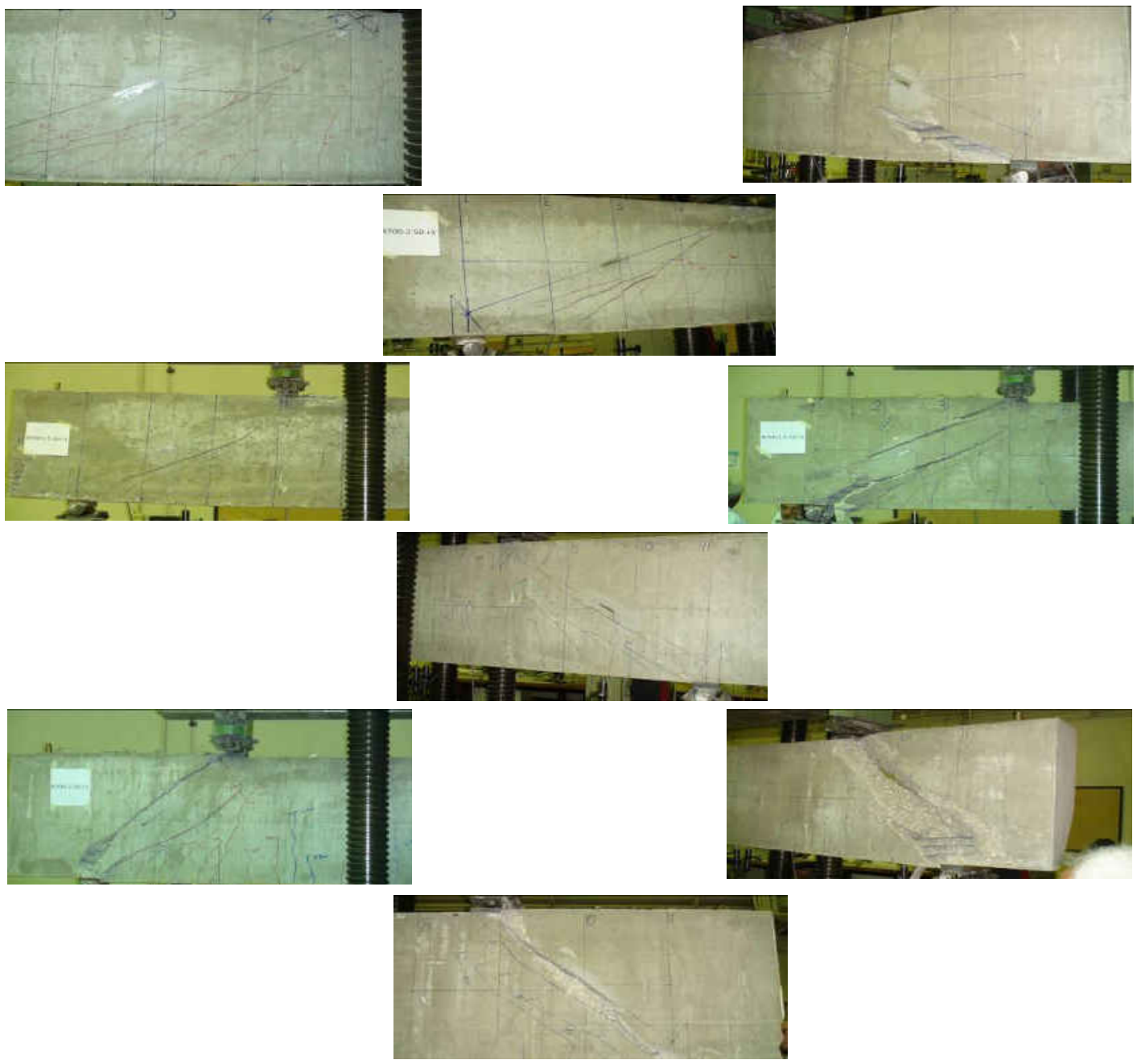

Journal of Engineering Sciences, Assiut University, Faculty of Engineering, Vol. 41, No. 4, July, 2013, E-mail address: jes@aun.edu.eg 
Ahmed I. Ramadan, et al., Shear Response Investigation of Hsrc Deep Beams without Web Reinforcement Part I: Comparison of Design Equations, pp. 1432 - 1446
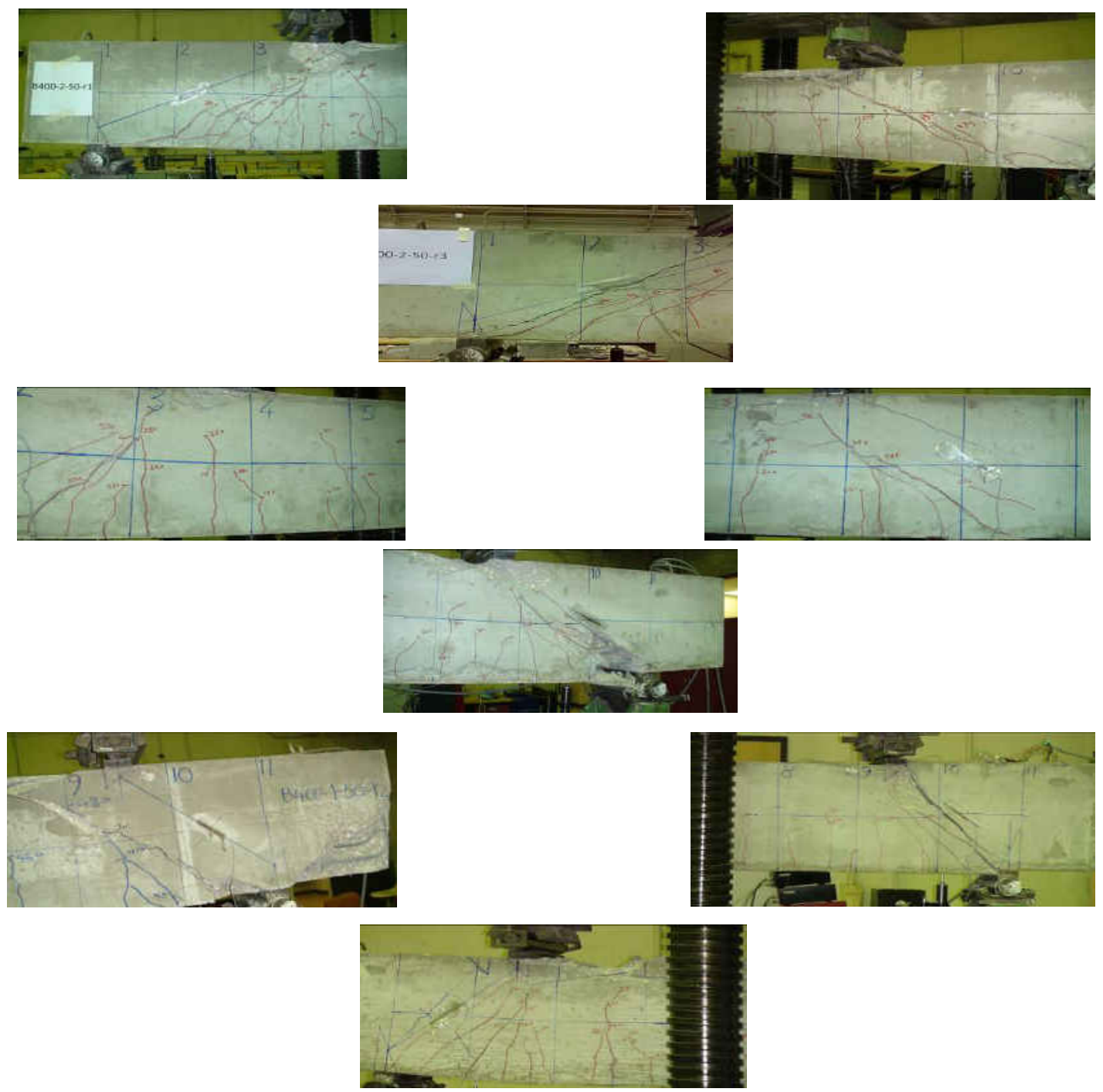

Fig. 9. Failure modes for some tested Beams

\section{3. Load-deflection curves}

The load-deflection responses of all beams appear to be non-linear. The deflection increases at beginning linearly then trend be non-linear with loading. Some of the load deflection curves have been given in Figs. 10, 11; show the mid-span deflections against the applied loads for beams have varying steel ratio of $\rho s \%$ and constant $\mathrm{a} / \mathrm{d}$ ratios. The load-deflection curves for beams with $\mathrm{a} / \mathrm{d}=1$ are steeper than those with $\mathrm{a} / \mathrm{d}$ of 1.5 and 2 . The deflections at ultimate loads of beams with a/d of 1.5 and 2 are greater than those

Journal of Engineering Sciences, Assiut University, Faculty of Engineering, Vol. 41, No. 4, July, 2013,E-mail address: jes@aun.edu.eg 
Ahmed I. Ramadan, et al., Shear Response Investigation of Hsrc Deep Beams without Web Reinforcement Part I: Comparison of Design Equations, pp. 1432 - 1446

when $\mathrm{a} / \mathrm{d}=1$. Thus stiffness, as represented by the load deflection curves, reduces as $\mathrm{a} / \mathrm{d}$ increases.

The ultimate load decreased as the a/d increased. This is due to the strut and tie action (tied-arch action) effect which becomes greater as the a/d gets smaller.

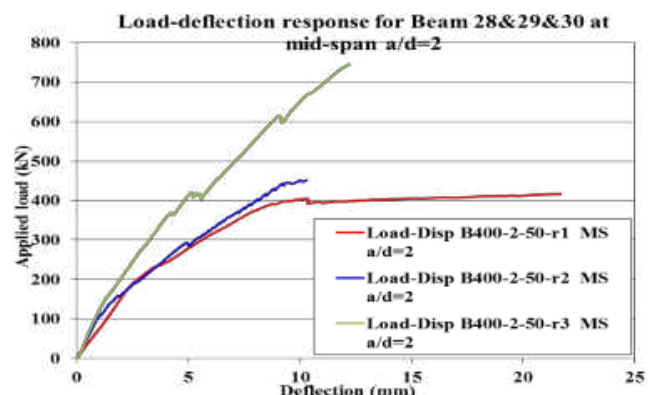

a) at mid span

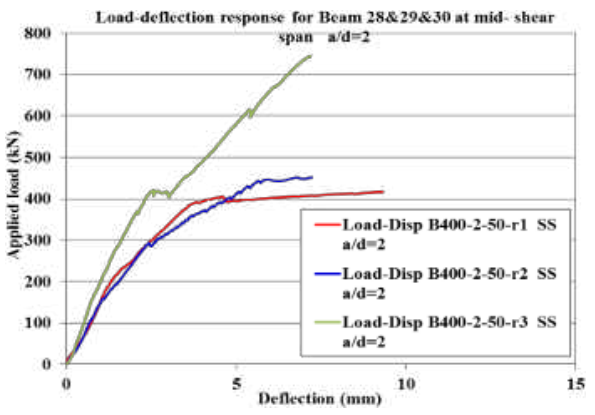

b) at mid-shear span

Fig. 10. Load-Deflection relationship for Beams $10 \& 11 \& 12$

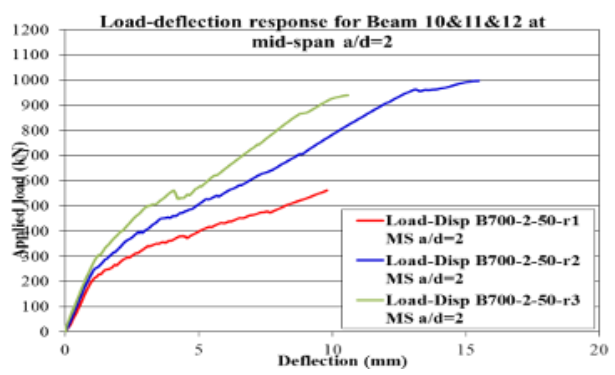

a) at mid span

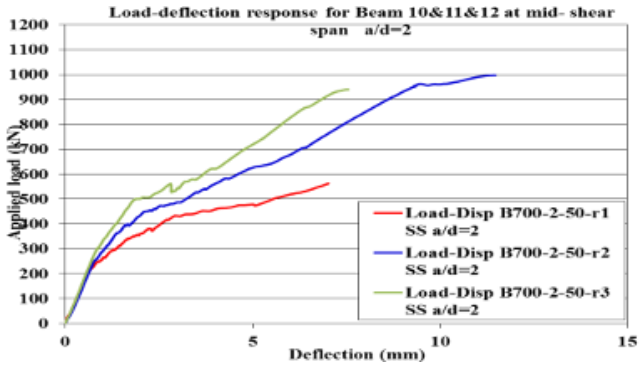

b) at mid-shear span

Fig. 11. Load-Deflection relationship for Beams $28 \& 29 \& 30$

\section{4. Effect of $(a / d)$ on Shear Strength of HSRC deep Beams}

The shear span to depth a/d ratio has a strong influence on the shear strength of HSRC beams like NSRC beams. The shear strength decreases with the increase of a/d values for the same longitudinal steel. The increase in shear span increases the number of cracks formed and that is happened due to cantilever force applied at the cracked concrete, reducing the shear strength of concrete to greater extent. The effect of a/d values on the shear strength of HSRC beams has been shown in Fig 12, 13.

Journal of Engineering Sciences, Assiut University, Faculty of Engineering, Vol. 41, No. 4, July, 2013,E-mail address: jes@aun.edu.eg 
Ahmed I. Ramadan, et al., Shear Response Investigation of Hsrc Deep Beams without Web Reinforcement Part I: Comparison of Design Equations, pp. 1432 - 1446

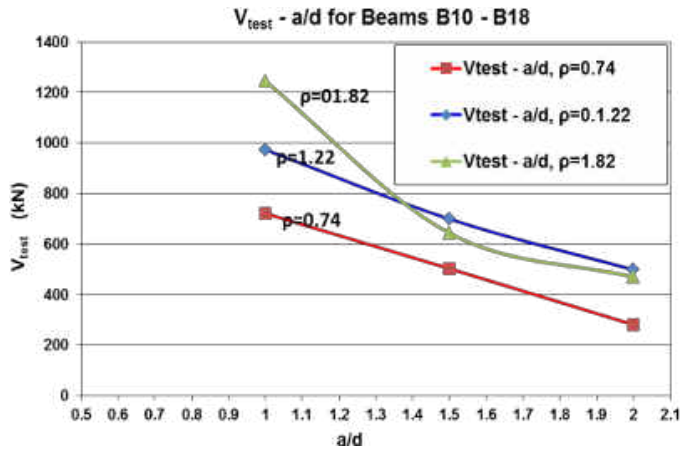

Fig. 12. $\left(\mathrm{V}_{\text {test }} \mathrm{t}^{\mathrm{a}} / \mathrm{d}\right)$ diagram for $\mathrm{B} 10-\mathrm{B} 18$

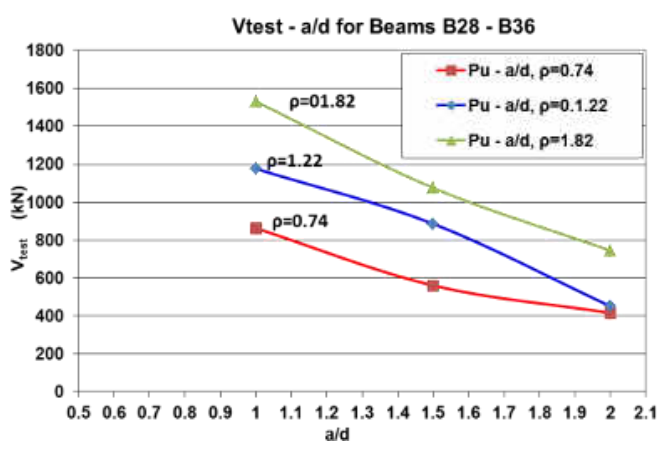

Fig. 13. $\left(\mathrm{V}_{\text {test }} \mathrm{-a} / \mathrm{d}\right)$ diagram for $\mathrm{B} 28-\mathrm{B} 36$

\section{5. Effect of ( $\rho$ s \%) on Shear Strength of HSRC deep Beams}

The tests have demonstrated that the beams reinforced with higher $\rho$ s \% exhibited fewer strains in the longitudinal steel than those reinforced with lower $\rho$ \% $\%$ Fig 14, 15, due to increases in the ultimate shear capacity and reduces the deflection. An increase was recorded in values of Vtest /Vpred. as the steel percentage was increased, Table 3\&4. The increase is mainly due to the dowel action which improves with the amount of longitudinal steel crossing the cracks. Hence, it may be noted that the tensile reinforcement significantly affects the deflection of a beam, thus this is the most important parameter in controlling deflections of HSC beams. The effect of a/d values on the shear strength of HSRC beams has been shown in Fig 16, 17.

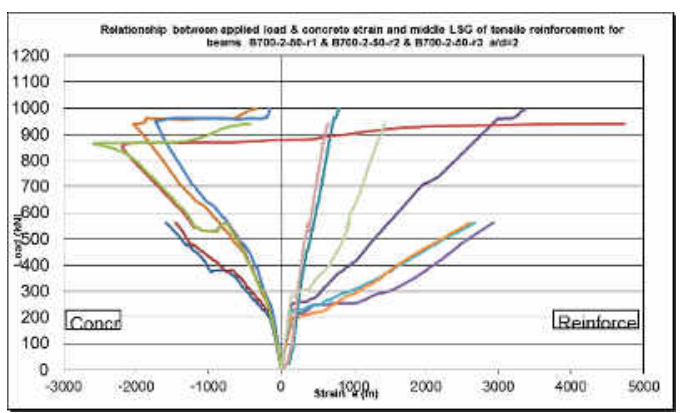

a) ( $\mathrm{P}_{\text {applied }} \& \varepsilon_{\mathrm{c}}$ and $\varepsilon_{\text {mid.LSG }}$ of tensile reinf.)

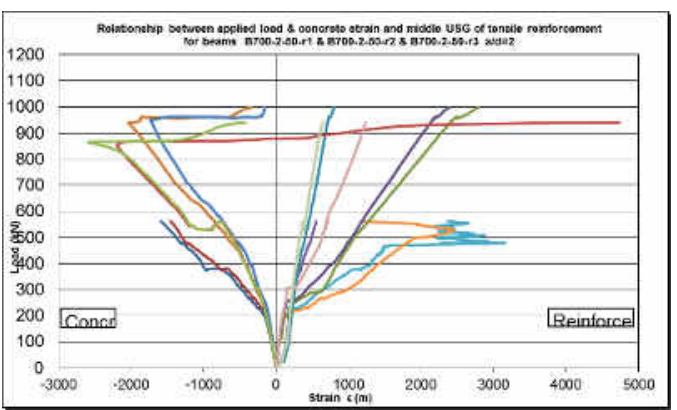

b) ( $\mathrm{P}_{\text {applied }} \& \varepsilon_{\mathrm{c}}$ and $\varepsilon_{\text {mid.USG }}$ of tensile reinf.)

Fig. 14. Relationships for Beams 10\&11\&12

Journal of Engineering Sciences, Assiut University, Faculty of Engineering, Vol. 41, No. 4, July, 2013,E-mail address: jes@aun.edu.eg 
1442

Ahmed I. Ramadan, et al., Shear Response Investigation of Hsrc Deep Beams without Web Reinforcement Part I: Comparison of Design Equations, pp. 1432 - 1446

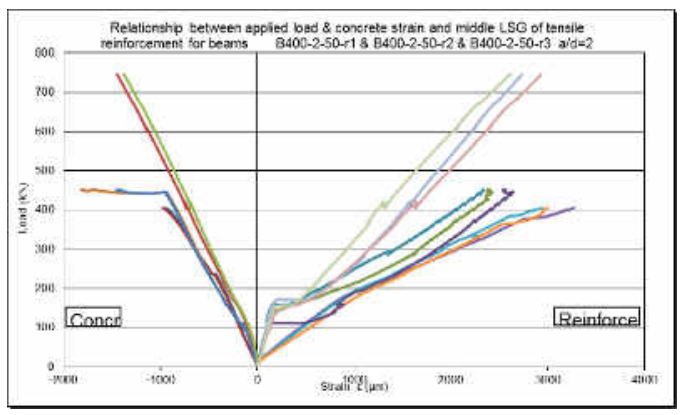

a) ( $\mathrm{P}_{\text {applied }} \& \varepsilon_{\mathrm{c}}$ and $\varepsilon_{\text {mid.LSG }}$ of tensile reinf.)

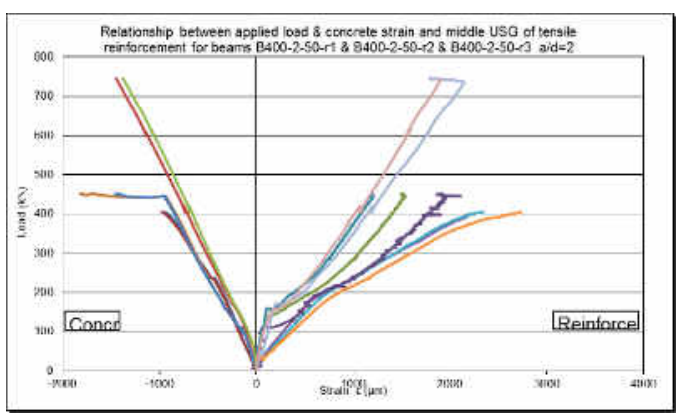

b) $\left(\mathrm{P}_{\text {applied }} \& \varepsilon_{\mathrm{c}}\right.$ and $\varepsilon_{\text {mid.USG }}$ of tensile reinf. $)$

Fig. 15. Relationships for Beams $28 \& 29 \& 30$

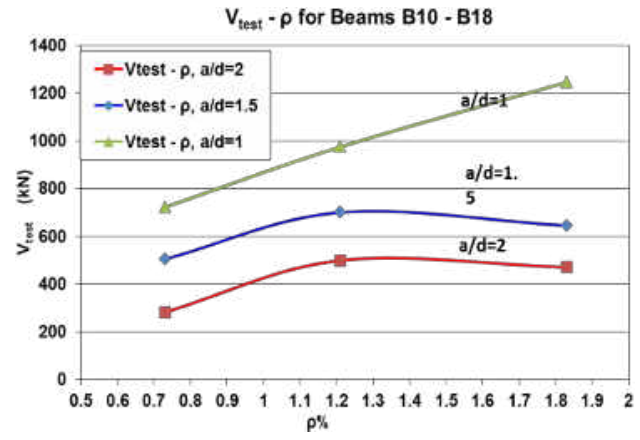

Fig. 16. $\left(\mathrm{V}_{\text {test }}-\rho \%\right), \mathrm{B} 10-\mathrm{B} 18$

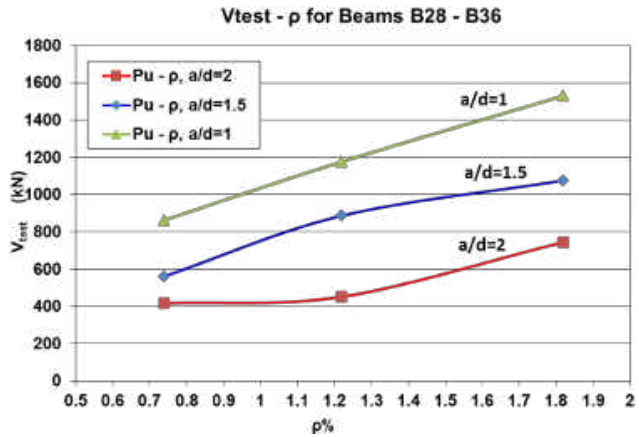

Fig. 17. $\left(V_{\text {test }^{-}}-\rho \%\right), B 28-B 36$

$\mathrm{a} / \mathrm{d}$ ratio and $\rho$ s have a significant effect on the shear capacity of a beam without web reinforcement. The shear carrying capacity of HSC beams was observed to decrease at a greater rate with the increase in a/d ratio, and thereafter a gradual decrease was noted. Fig. 18-20 for $\mathrm{h}=400 \mathrm{~mm}$ and Fig. $21-23$ for $\mathrm{h}=700 \mathrm{~mm}$ shows the variation in Vexp/Vpred. with $\mathrm{a} / \mathrm{d}$ ratio for different tensile steel ratios.

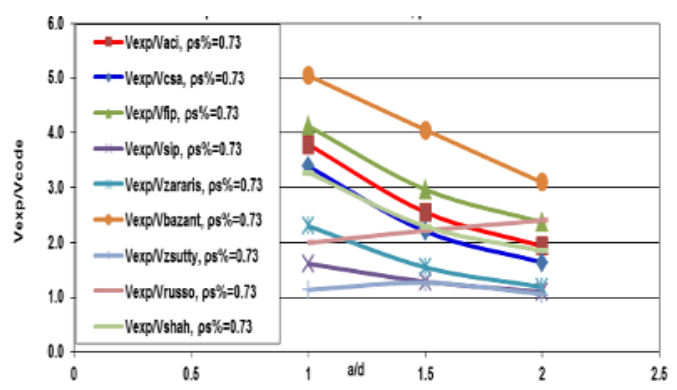

Fig. $18\left(\mathrm{~V}_{\text {exp }} / \mathrm{V}_{\text {pred }}-\mathrm{a} / \mathrm{d}\right), \mathrm{h}=400 \mathrm{~mm}, \rho \mathrm{s} \%=0.73$

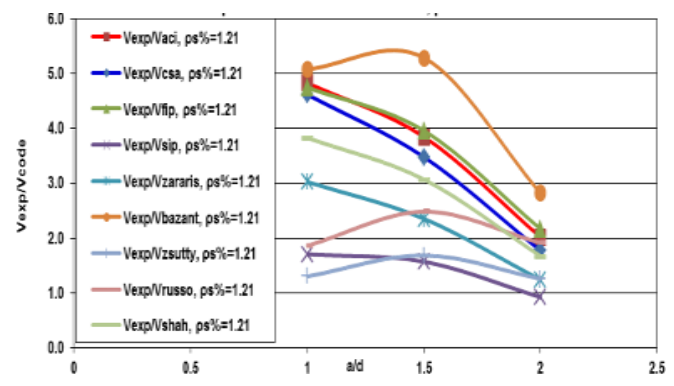

Fig. $19\left(V_{\text {exp }} / V_{\text {pred }}-\mathrm{a} / \mathrm{d}\right), \mathrm{h}=400 \mathrm{~mm}, \rho \mathrm{s} \%=1.21$

Journal of Engineering Sciences, Assiut University, Faculty of Engineering, Vol. 41, No. 4, July, 2013, E-mail address: jes@aun.edu.eg 
Ahmed I. Ramadan, et al., Shear Response Investigation of Hsrc Deep Beams without Web Reinforcement Part I: Comparison of Design Equations, pp. 1432 - 1446
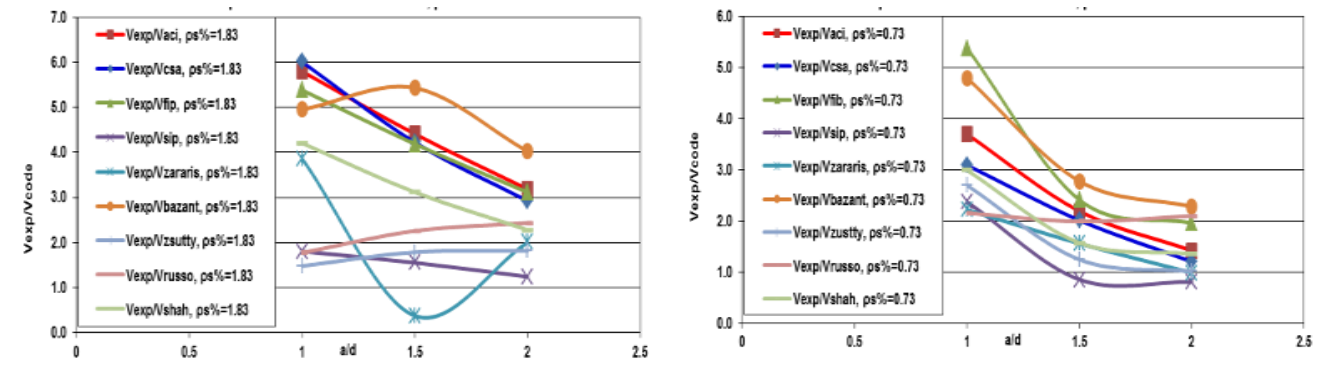

Fig. 20. (Vexp/Vpred.-a/d), $, \mathrm{h}=400 \mathrm{~mm}, \rho s^{\mathrm{o}} \%=1.83$
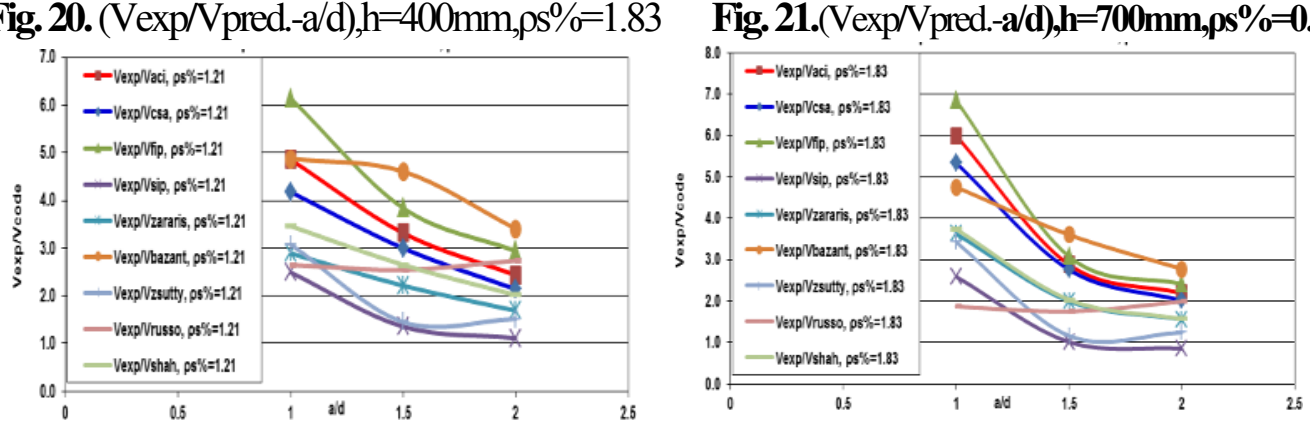

Fig. 22. (Vexp/Vpred.-a/d), $h=700 \mathrm{~mm}, \rho s \%=1.21 \quad$ Fig. 23. (Vexp/Vpred.-a/d), $\mathrm{h}=700 \mathrm{~mm}, \mathrm{ps} \%=1.83$

Table 3.

Comparisons of $\mathrm{V}_{\text {test }} / \mathrm{V}_{\text {pred. }}$ values at constant value of $\mathrm{a} / \mathrm{d}, \mathrm{h}=700 \mathrm{~mm}$

\begin{tabular}{|c|c|c|c|c|c|c|c|c|c|c|}
\hline \multirow{2}{*}{ a/d } & \multicolumn{10}{|c|}{$\mathrm{V}_{\text {exp }} / \mathbf{V}_{\text {pred. }} \quad h=700 \mathrm{~mm}$} \\
\hline & $\rho_{s} \%$ & $A C I$ & $\overrightarrow{C S A}$ & $\vec{F} \bar{B}$ & $S I P$ & Zararis & Bazant & Zsutty & Russo & Shah \\
\hline \multirow{3}{*}{2} & 0.73 & 1.4 & 1.2 & 2.0 & 0.8 & 1.0 & 2.3 & 1.0 & 2.1 & 1.4 \\
\hline & 1.21 & 2.4 & 2.1 & 2.9 & 1.1 & 1.7 & 3.4 & 1.5 & 2.7 & 2.0 \\
\hline & 1.83 & 2.2 & 2.0 & 2.4 & 0.9 & 1.6 & 2.8 & 1.2 & 2.0 & 1.6 \\
\hline \multirow{3}{*}{1.5} & 0.73 & 2.5 & 2.2 & 3.3 & 1.3 & 1.7 & 4.0 & 1.2 & 2.6 & 2.2 \\
\hline & 1.21 & 3.3 & 3.0 & 3.8 & 1.4 & 2.2 & 4.6 & 1.5 & 2.5 & 2.6 \\
\hline & 1.83 & 2.9 & 2.8 & 3.1 & 1.0 & 2.0 & 3.6 & 1.2 & 1.8 & 2.0 \\
\hline \multirow{3}{*}{1} & 0.73 & 3.7 & 3.1 & 5.4 & 2.4 & 2.2 & 4.8 & 2.7 & 2.2 & 3.0 \\
\hline & 1.21 & 4.9 & 4.2 & 6.1 & 2.5 & 2.9 & 4.9 & 3.1 & 2.7 & 3.5 \\
\hline & 1.83 & 6.0 & 5.3 & 6.8 & 2.6 & 3.6 & 4.8 & 3.4 & 1.9 & 3.7 \\
\hline
\end{tabular}

Table 4.

Comparisons of Vtest $/$ pred. values at constant value of $\mathrm{a} / \mathrm{d}, \mathrm{h}=400 \mathrm{~mm}$

\begin{tabular}{|c|c|c|c|c|c|c|c|c|c|c|}
\hline \multirow{2}{*}{$\mathbf{a} / \mathbf{d}$} & \multicolumn{10}{|c|}{$\mathrm{V}_{\text {exp }} / \mathrm{V}_{\text {pred. }} \quad h=400 \mathrm{~mm}$} \\
\hline & $\rho_{\mathrm{s}} \%$ & $A C I$ & $\overline{C S A}$ & $\vec{F} B$ & SIP & Zararis & Bazant & Zsutty & Russo & Shah \\
\hline \multirow{3}{*}{2} & 0.73 & 1.9 & 1.6 & 2.4 & 1.1 & 1.2 & 3.1 & 1.1 & 2.4 & 1.8 \\
\hline & 1.21 & 2.0 & 1.8 & 2.2 & 0.9 & 1.2 & 2.8 & 1.3 & 1.9 & 1.7 \\
\hline & 1.83 & 3.2 & 2.9 & 3.1 & 1.2 & 2.0 & 4.0 & 1.8 & 2.4 & 2.3 \\
\hline \multirow{3}{*}{1.5} & 0.73 & 2.6 & 2.2 & 3.0 & 1.3 & 1.5 & 4.1 & 1.3 & 2.2 & 2.3 \\
\hline & 1.21 & 3.8 & 3.5 & 4.0 & 1.6 & 2.4 & 5.3 & 1.7 & 2.5 & 3.1 \\
\hline & 1.83 & 4.4 & 4.2 & 4.2 & 1.6 & 0.4 & 5.4 & 1.8 & 2.3 & 3.1 \\
\hline \multirow{3}{*}{1} & $\mathbf{0 . 7 3}$ & 3.8 & 3.4 & 4.1 & 1.6 & 2.3 & 5.0 & 1.1 & 2.0 & 3.3 \\
\hline & 1.21 & 4.8 & 4.6 & 4.8 & 1.7 & 3.0 & 5.1 & 1.3 & 1.9 & 3.8 \\
\hline & 1.83 & 5.8 & 6.0 & 5.4 & 1.8 & 3.9 & $\overline{5.0}$ & 1.5 & 1.8 & 4.2 \\
\hline
\end{tabular}

Journal of Engineering Sciences, Assiut University, Faculty of Engineering, Vol. 41, No. 4, July, 2013, E-mail address: jes@aun.edu.eg 
Ahmed I. Ramadan, et al., Shear Response Investigation of Hsrc Deep Beams without Web Reinforcement Part I: Comparison of Design Equations, pp. 1432 - 1446

Comparison of the experimental results with ACI, CSA, FIP, and the equations proposed by SIP, Zararis, Bazant, Zsutty, Russo, and Shah show that the a/d ratio significantly effects the shear carrying capacity and mode of failure of the tested beams. The shear strength of the beams decreases on increasing the shear span to depth ratio $(\mathrm{a} / \mathrm{d})$, where shear strength increased as compared to the various design approaches and brittle failure of the beams was observed.

It can be observed that the average values of Vexp/Vpred. increases steadily with increasing in longitudinal reinforcement ratio, which shows that, there is a pronounced effect of tensile steel on the ultimate load and shear capacity of members without shear reinforcement. For a constant value of a/d ratio, the relative flexural strength decreases and failure load increases with an increase in longitudinal reinforcement ratio therefore, quantitative effect of tensile steel was observed on shear capacity of reinforced concrete beams.

ACI 318-11 shows underestimate on shear capacity of a beam without web reinforcement, where experimental results show that the tensile steel has significant effect on shear carrying capacity. Also, it can be observed that the current ACI shear provision is unconservative for high strength concrete beams without web reinforcement with lower values of longitudinal reinforcement ratios. It can be observed that Canadian and FIP codes also underestimate the shear strength of reinforced concrete beams for lower a/d ratios up to 2 , and thereafter overestimate.

\section{Conclusions}

In this study eighteen HSRC deep beams were tested to evaluate the contributions of $\mathbf{a} / \mathbf{d}$ and $\rho_{\mathrm{s}} \%$ on the global behavior in shear. Based on the experimental results obtained, the following conclusions are drawn:

1) Hsrc deep beams without stirrups exhibit a brittle behaviour.

2) The mode of failure was significantly altered by changing the beam depth. Sufficient ductility was achieved in small size beams, whereas relatively very high brittleness was observed in large size beams.

3) The failure in most of the beams has been caused due to diagonal tension cracking; however it was more dominant failure mode for beams without web reinforcement and having $\rho=1.21 \& 1.83 \%$. For beams with $\rho=0.73 \%$, flexural shear failure was obvious failure mode.

4) For beams have large values of longitudinal steel, the shear failure is more brittle and sudden, giving no sufficient warning.

5) An increase in longitudinal steel ratio increases the ultimate shear capacity and reduces the deflection at mid-span; an increase of $73 \%$ was recorded between beam b700-1-50r1 and beam b700-1-50-r3 where the steel percentage increased from 0.73 to $1.83 \%$;

6) Ultimate load decreases as $\mathrm{a} / \mathrm{d}$ increases. In the same manner, mid-span deflections at ultimate load increase as the values of a/d increase; flexural behavior is more associated with a beam action as a/d increases.

7) Aci and fib codes are safe for use with the exception that csa should be used with care; it might have a tight safety margin against brittle shear failures.

Journal of Engineering Sciences, Assiut University, Faculty of Engineering, Vol. 41, No. 4, July, 2013,E-mail address: jes@aun.edu.eg 
Ahmed I. Ramadan, et al., Shear Response Investigation of Hsrc Deep Beams without Web Reinforcement Part I: Comparison of Design Equations, pp. 1432 - 1446

8) The different design equations considered in this study do not accurately reflect the increase in shear capacity of beams with shorter shear spans $(a / d=1.5)$. Most of the design models are excessively conservative, and the code predictions only seem to be more accurate as a/d increases beyond a value of 2.0 .

\section{References}

[1] FIP Recommendations 1996, Practical Design of Structural Concrete, Fédération Internationale de la Precontrainte 1996.

[2] Design of Concrete Structures, CSA Standard A23.3-94, Canadian Standards Assoc., 1994.

[3] Building Code Requirements for Structural Concrete (318-99), American Conc. Inst., 1999.

[4] Sudheer Reddy L., Ramana Rao N. V. and Gunneswara Rao T. D., "Evaluation of shear resistance of high strength concrete beams without web reinforcement using ANSYS", ARPN Journal of Engineering and Applied Sciences, February 2011, Vol. 6, No. 2.

[5] Zararis, P."Shear Compression Failure in Reinforced Concrete Deep Beams." J. Struct. Eng., (2003), 129(4), 544-553.

[6] P.D. Zararis, "Shear Strength and Minimum Shear Reinforcement of Reinforced Concrete Slender Beams," ACI Structural Journal, 100(2)(2003), pp. 203-214.

[7] T. C. Zsutty, "Shear Strength Predictions for Separate Categories of Simple Beam Tests", ACI Journal, Proceedings, 68(2)(1971), pp. 138-143.

[8] Shah, Attaullah (2009), "Evaluation of Shear Strenth of High Strenght Concrete Beams". $\mathrm{PhD}$ thesis, University of Engineering \& Technology, Taxila.

[9] Bazant, Z.P and Kim J.K ., (1984) "The Size effect in shear Failure of longitudinally reinforced Beams" ACI Structural Journal Vol.81 (5), pp.456-468.

[10] Gaetano Russo, Denis Mitri, Margherita Pauletta "Shear strength analysis and prediction for reinforced concrete beams without stirrups", Journal of Structural Engineering, v 131, n 12, p 1936, December 2005.

[11] P.M. Ferguson, "Some Implications of Recent Diagonal Tension Tests", Journal of ACI, 28(2)(1956), pp. 157-172.

[12] R. Taylor, "Some Shear Tests on Reinforced Concrete Beams Without Shear Reinforcement", Magazine of Concrete Research, 12(36)(1960), pp. 145-154.

[13] R.D. Cossio and X. Chester, "Behavior and Strength in Shear of Beams and Frames Without Web Reinforcement", Journal of ACI, 1960, pp. 695-705.

[14] F. J. Berg, "Shear Strength of Reinforced Concrete Beams Without Web Reinforcement", Journal of ACI, 59(11)(1962), pp. 1587-1599.

[15] R. Mathey and D. Watstein, "Shear Strength of Beams without Web Reinforcement Containing Deformed Bars of Different Yield Strengths", Journal of ACI, V.60, No. 2, Feb.1963, pp. 197-206.

[16] T. C. Zsutty, "Shear Strength Predictions for Separate Categories of Simple Beam Tests", ACI Journal, Proceedings, 68(2)(1971), pp. 138-143.

[17] G.N.J. Kani, "Basic Facts Concerning Shear Failure”, Journal of ACI, 1966, pp. 675-692.

[18] A. H. Elzanaty, A. H. Nilson, and F.O. Slate, "Shear Capacity of reinforced Concrete Beams Using High-strength Concrete", ACI Journal ,Proceedings, 83(2)(1986), pp. 290-296.

[19] J.J. Roller and H G. Russell., "Shear Strength of High-Strength Concrete Beams with Web Reinforcement", ACI Structural Journal, 87(2)(1990), pp. 191-198.

[20] S.H. Ahmed and D.M. Lue, "Flexure-Shear Interaction of Reinforced High-Strength Concrete Beams", ACI Structural Journal, 1987, pp. 330-341.

[21] B. Batchelor, "Shear in R.C. Beams Without Web Reinforcement", Journal of Structural Division, 107(ST5)(1981), pp. 907-919.

[22] S.W. Shin, K.S. Lee, J. Moon, and S.K. Ghosh, "Shear Strength of H.S.C. Beams with a/d 1.5 to 2.5”, ACI Structural Journal, 96(4)(1999), pp. 549-556.

Journal of Engineering Sciences, Assiut University, Faculty of Engineering, Vol. 41, No. 4, July, 2013,E-mail address: jes@aun.edu.eg 
Ahmed I. Ramadan, et al., Shear Response Investigation of Hsrc Deep Beams without Web Reinforcement Part I: Comparison of Design Equations, pp. 1432 - 1446

[23] W. Kim and R.N. White, "Shear Critical Cracking in Slender Reinforced Concrete Beams", ACI Structural Journal, 96(5)(1999), pp. 757-765.

[24] E.J. Tompos and R.J. Frosh, "Influence of Beam Size, Longitudinal Reinforcement, and Stirrup Effectiveness on Concrete Shear Strength", ACI Structural Journal, 2002, pp. 559-567.

[25] S.H. Ahmad, A.R. Khaloo, and A. Poveda, "Shear Capacity of Reinforced Concrete Beams", ACI Journal, Proceedings, 82(2)(1986), pp. 297-305.

[26] Reineck, K.-H.; Kuchma, D. A.; Kim, K. S.; and Marx, S., "Shear Database for Reinforced Concrete Members without Shear Reinforcement,"ACI Structural Journal, V. 100, No. 2, Mar.-Apr. 2003, pp. 240-249.

\section{Notations}

$\mathbf{a}=$ Shear span, distance between concentrated load and face of support, in $\mathrm{mm}$

$\mathbf{a}_{\mathbf{h}}=$ distance between two concentrated loads, in $\mathrm{mm}$

$\mathbf{a}_{\mathbf{r}}=$ distance between end of beam and face of support, in $\mathrm{mm}$

$\mathbf{b}=$ Beam width, in $\mathrm{mm}$

$\mathbf{d}=$ Effective beam depth, in $\mathrm{mm}$

$\mathbf{d}_{\mathbf{0}}=$ maximum aggregate size, in $\mathrm{mm}$

$\mathbf{f}_{\mathbf{c}}=$ Cylindrical compressive strength of concrete, in $\mathrm{MPa}$

$\boldsymbol{\rho}_{\mathrm{s}}=$ Ratio of Longitudinal reinforcement ratio; $=\mathrm{A}_{\mathrm{s}} / \mathrm{bd}$

$\mathrm{S}_{\mathrm{s}}=$ distance between two stirrups under concentrated loads, in $\mathrm{mm}$

\section{التحقق من إستجابة قوي القص للكمرات الخرسانية المسلحة عالية المقاومة العميقة

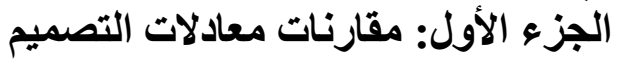

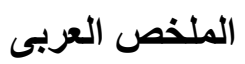

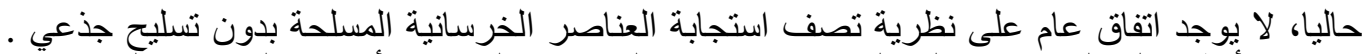

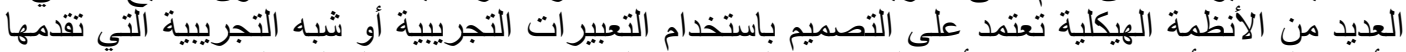

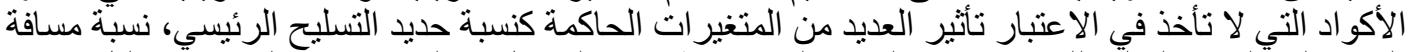

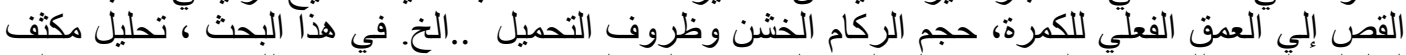

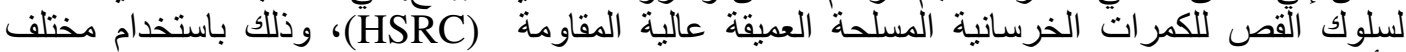

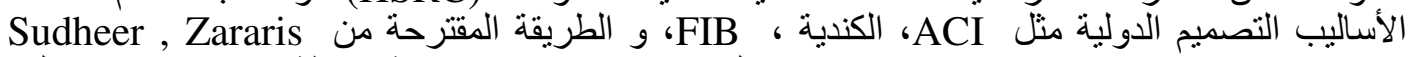
جذاعي Russo , Rsutty , Shah ,Bazant,

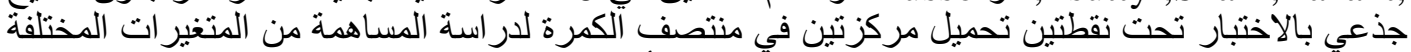

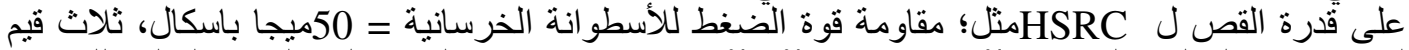

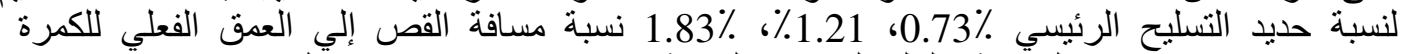

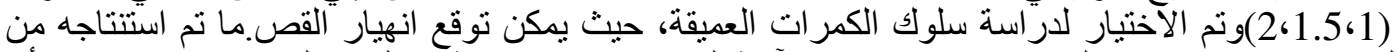

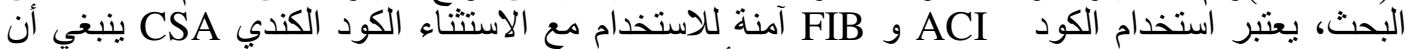

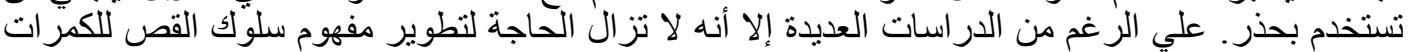

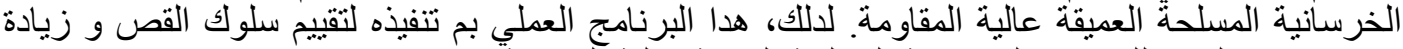

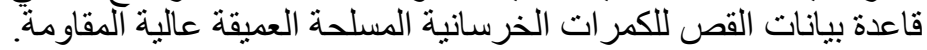

Journal of Engineering Sciences, Assiut University, Faculty of Engineering, Vol. 41, No. 4, July, 2013,E-mail address: jes@aun.edu.eg 